\title{
Hubungan aktivitas fisik dan kualitas tidur dengan dismenorea pada mahasiswi FK UPN “Veteran" Jakarta
}

\author{
Dwi Rafita Lestari, Mila Citrawati, Niniek Hardini \\ Fakultas Kedokteran UPN "Veteran", Jakarta
}

Korespondensi: Dwi Rafita Lestari,email: rft.dls@gmail.com

\begin{abstract}
Abstrak
Dismenorea menjadi gangguan menstruasi yang paling umum terjadi pada perempuan dewasa, sehingga memengaruhi kehidupan sehari-hari dan performa akademik. Dismenorea banyak dialami oleh perempuan muda pada rentang usia 18 - 25 tahun dan prevalensi dismenorea tertinggi terjadi pada mahasiswi. Tujuan: Mengetahui hubungan aktivitas fisik dan kualitas tidur dengan dismenorea pada mahasiswi Fakultas Kedokteran UPN “Veteran” Jakarta. Metode: Penelitian ini bersifat analitik observasional menggunakan desain potong lintang dengan sampel berjumlah 70 mahasiswi. Data dianalisis dengan uji Chi-Square, uji alternatif Mann Whitney dan uji regresi logistik. Instrumen penelitian menggunakan Global Physical Activity Questionnaire (GPAQ), Pittsburgh Sleep Quality Index (PSQI), dan Numeric Pain Rating Scale (NPRS) untuk menilai aktivitas fisik, kualitas tidur, dan derajat dismenorea. Hasil: Terdapat hubungan antara aktivitas fisik $(p=0,002)$ dan kualitas tidur $(p=0,004)$ dengan dismenorea pada mahasiswi Fakultas Kedokteran UPN “Veteran” Jakarta. Simpulan: Aktivitas fisik dan kualitas tidur memiliki hubungan yang bermakna dengan dismenorea. Kualitas tidur memiliki hubungan yang lebih kuat dengan dismenorea.
\end{abstract}

Kata kunci: aktivitas fisik; kualitas tidur; dismenorea

\begin{abstract}
Dysmenorrhea is the most common menstrual disorder in adult women, thus affecting daily life and academic performance. Dysmenorrhea is mostly experienced by young women in the age range of 1825 years and the highest prevalence of dysmenorrhoea occurs in female students. Objectives: The study was conducted to identify the relation between physical activity and quality of sleep among medical students in Pembangunan Nasional "Veteran" Jakarta University. Methods: This study was an observational analytical research with cross sectional design. The samples of the research were 70 medical students. The data was analyzed by using Chi-Square test, Mann Whitney alternative test and logistic regression test. The instruments of the research were GPAQ, PSQI, and NPRS to assess physical activity, quality of sleep, and severity of dysmenorrhea. Results: This study proved that there was a relation between physical activity $(p=0.002)$ and quality of sleep $(p=0.004)$ to dysmenorrhea among medical students in Pembangunan Nasional "Veteran" Jakarta University. Conclusions: Both physical activity and quality of sleep had a relation to dysmenorrhea. Quality of sleep had stronger relation to dysmenorrhea than physical activity.
\end{abstract}

Keywords: physical activity; quality of sleep; dysmenorrhea 


\section{PENDAHULUAN}

Salah satu keluhan ginekologi yang paling sering dirasakan oleh perempuan usia produktif adalah menstruasi yang menyakitkan (dismenorea). Prevalensi dismenorea di dunia berkisar 15,8 - 89,5 \% dengan nilai tertinggi pada populasi dewasa. ${ }^{1}$ Dismenorea berdampak pada individu dan komunitas, seperti tingginya ketidakhadiran di sekolah dan pekerjaan, gangguan aktivitas sehari-hari, dan banyaknya penggunaan obat sedatif. ${ }^{2,3}$ Dismenorea menjadi gangguan menstruasi yang paling umum terjadi pada perempuan dewasa, sehingga memengaruhi kehidupan sehari-hari dan performa akademik. $^{4}$

Dismenorea mengakibatkan 10-15\% perempuan tidak masuk kerja selama 1-3 hari dan sekitar $50 \%$ perempuan di dunia, mengalami dismenorea kategori berat. $^{5}$ Studi di Amerika menyebutkan bahwa 140 juta jam kerja hilang akibat dismenorea. ${ }^{6}$ Dismenorea banyak dialami oleh perempuan muda pada rentang usia 18 25 tahun dan berkurang seiring bertambahnya usia. ${ }^{7,8}$ Prevalensi dismenorea tertinggi terjadi pada mahasiswi dengan persentase 34,2\% termasuk nyeri berat; $36,6 \%$ nyeri sedang; dan $29,2 \%$ nyeri ringan. ${ }^{9}$

Dismenorea diklasifikasikan menjadi primer dan sekunder. Dismenorea primer adalah perasaan sangat nyeri saat menstruasi yang terjadi tanpa kelainan ginekologi, sering dimulai pada 6-12 bulan setelah menarche, dan dapat berlanjut hingga menopause, serta terjadi bersamaan dengan menstruasi dan dapat berlanjut selama 8 jam sampai 3 hari. Dismenorea sekunder dapat terjadi kapan saja pada kehidupan perempuan, antara menarche dan menopause, namun paling sering terjadi setelah usia 25 tahun, dengan adanya keadaan patologis yang mendasari, seperti endometriosis dan kista ovarium. ${ }^{10}$ Indonesia memiliki prevalensi dismenorea sebesar 64,25\%, terdiri dari dismenorea primer sebesar $54,89 \%$ dan 9,36\% mengalami dismenorea sekunder. ${ }^{11}$ World Health Organization (WHO) tahun 2018 mengemukakan bahwa secara global, perempuan (84\%) memiliki persentase kurangnya aktivitas fisik yang lebih tinggi daripada laki-laki (78\%). ${ }^{12}$ Persentase perempuan yang lebih tinggi ini, akibat kurangnya aktivitas fisik pada waktu luang dan penerapan gaya hidup malas bergerak, ketika dirumah maupun saat bekerja. Perempuan di Indonesia memiliki gaya hidup kurang gerak atau memiliki intensitas aktivitas fisik dalam kategori rendah. ${ }^{13}$ Kurangnya aktivitas fisik akan menurunkan distribusi oksigen dalam sirkulasi sistemik, sehingga meningkatkan persepi seseorang terhadap nyeri, termasuk dismenorea. Perempuan yang aktif secara fisik, dilaporkan kurang mengalami dismenorea dan berolahraga sekurang-kurangnya satu kali seminggu, dapat mengurangi nyeri perut bawah. ${ }^{14}$ Dismenorea terjadi pada 54,6\% mahasiswi yang memiliki aktivitas fisik mingguan yang rendah, sehingga aktivitas fisik yang rendah tersebut, cenderung dihubungkan dengan terjadinya dismenorea. ${ }^{15}$ 
Selain aktivitas fisik, kualitas tidur yang merupakan fenomena kompleks dan berkaitan dengan kepuasan seseorang terhadap tidur, juga dapat memengaruhi persepsi seseorang terhadap nyeri. Tidur yang terganggu, akan berkontribusi langsung dalam menyebabkan hiperalgesia. Perempuan dengan efisiensi tidur yang rendah dan kualitas tidur yang buruk, akan mengalami derajat dismenorea yang berat. ${ }^{16,17}$ Dewasa muda dan mahasiswa, memiliki prevalensi kualitas tidur buruk yang tinggi dengan persentase sebesar 19,17-57,5\% dan tertinggi pada mahasiswa kedokteran. ${ }^{18}$ Kualitas tidur yang buruk pada mahasiswa kedokteran, terutama dialami oleh perempuan dengan 54\% mahasiswi memiliki pola tidur abnormal. ${ }^{19}$ Perempuan dengan insomnia, cenderung mengalami dismenorea dengan derajat yang lebih berat dibandingkan yang tidak. ${ }^{20}$ Adanya gangguan tidur tersebut, akan semakin meningkatkan sensitivitas tubuh terhadap nyeri, yang kemudian meningkatkan derajat dismenorea. ${ }^{21,22}$

\section{METODE}

Jenis penelitian yang digunakan adalah analitik observasional dengan desain cross sectional. Populasi pada penelitian ini adalah adalah seluruh Mahasiswi Fakultas Kedokteran UPN "Veteran" Jakarta. Sampel dalam penelitian ini adalah Mahasiswi Fakultas Kedokteran UPN "Veteran" Jakarta yang memenuhi kriteria inklusi subjek penelitian sebanyak 70 orang. Kriteria inklusi penelitian ini adalah usia 18-25 tahun, indeks massa tubuh normoweight, mengalami nyeri haid selama minimal 3 bulan terakhir, onset menarche $\geq 12$ tahun. Kriteria eksklusi penelitian ini adalah memiliki riwayat penyakit/kelainan ginekologi (endometriosis, adenomiosis, fibroid), merokok, dan konsumsi alkohol. Pengambilan sampel dalam penelitian ini menggunakan metode non probability sampling dengan teknik purposive sampling. Data yang digunakan dalam penelitian ini merupakan data primer berupa kuesioner karakteristik menstruasi yang disertai Numerical Rating Scale (NRS) untuk menilai intensitas dismenorea, Pittsburgh Sleep Quality Index (PSQI) untuk menilai kualitas tidur, dan Global Physical Activity Questionnaire (GPAQ) untuk menilai tingkat aktivitas fisik. Analisis hipotesis dilakukan dengan analisis univariat, bivariat, dan multivariat. Penelitian ini menggunakan uji Chi-Square. Uji yang digunakan untuk analisis multivariat adalah uji regresi logistik.

\section{HASIL DAN PEMBAHASAN}

Berdasarkan tabel 1 didapatkan hasil bahwa sebagian besar responden berusia 20 tahun (75,7\%), mengalami menarche pada usia 12 tahun (50\%), memiliki tingkat aktivitas fisik yang rendah (64,3\%), memiliki kualitas tidur yang buruk (82,9\%), dan mengalami dismenorea derajat sedang (55,7\%). Hasil tabulasi silang antara aktivitas fisik dengan dismenorea menunjukkan bahwa sebanyak 17 responden $(37,8 \%)$ dalam kelompok 
aktivitas fisik intensitas rendah, mengalami dismenorea derajat berat, 25 responden $(55,6 \%)$ dengan aktivitas fisik yang rendah, mengalami dismenorea derajat sedang, serta hanya terdapat 3 responden $(6,7 \%)$ dengan aktivitas fisik sehari-hari yang rendah, namun mengalami dismenorea derajat ringan. Responden dengan aktivitas fisik intensitas tinggi, mengalami dismenorea derajat ringan sebanyak 4 responden (50\%), 2 responden (25\%) mengalami dismenorea derajat sedang, dan 2 responden (25\%) mengalami dismenorea derajat berat.

Hasil analisis bivariat menggunakan uji ChiSquare didapatkan nilai $p<0,05 \quad(p=0,002)$ menunjukkan adanya hubungan yang bermakna antara aktivitas fisik dengan dismenorea. Setelah dilakukan uji alternatif Mann Whitney, didapatkan bahwa responden dengan tingkat aktivitas fisik rendah (Mean Rank 40,48), cenderung lebih berisiko mengalami dismenorea yang lebih berat. Berdasarkan hasil analisis hubungan kualitas tidur dengan dismenorea, diketahui bahwa responden dengan kualitas tidur buruk, mengalami dismenorea derajat berat sebanyak 17 responden $(29,3 \%)$, dismenorea derajat sedang sebanyak 38 responden $(65,5 \%)$, dan dismenorea derajat ringan sebanyak 3 responden $(5,2 \%)$.

Tabel 1. Distribusi karakteristik responden

\begin{tabular}{lcc}
\hline Karakteristik & Frekuensi (n) & $\begin{array}{c}\text { Presentase } \\
(\%)\end{array}$ \\
\hline Usia & 7 & 10,0 \\
19 tahun & 53 & 75,7 \\
20 tahun & 10 & 14,3 \\
21 tahun & & \\
Onset & & \\
menarche & 35 & 50,0 \\
12 tahun & 27 & 38,6 \\
13 tahun & 8 & 11,4 \\
14 tahun & & \\
Aktivitas fisik & 45 & 64,3 \\
Rendah & 17 & 24,3 \\
Menengah & 8 & 11,4 \\
Tinggi & & \\
Kualitas tidur & 12 & 17,1 \\
Baik & 58 & 82,9 \\
Buruk & & 15,7 \\
Dismenorea & 11 & 55,7 \\
Ringan & 39 & 28,6 \\
Menengah & 20 & \\
Berat & & \\
\hline & &
\end{tabular}

Tabel 2. Analisis bivariat hubungan aktivitas fisik dengan dismenorea pada mahasiswi Fakultas Kedokteran UPN “Veteran" Jakarta

\begin{tabular}{|c|c|c|c|c|c|c|c|c|c|}
\hline \multirow{3}{*}{$\begin{array}{l}\text { Aktivitas } \\
\text { fisik }\end{array}$} & \multicolumn{6}{|c|}{ Dismenorea } & \multicolumn{2}{|c|}{ Total } & \multirow[t]{3}{*}{$p$} \\
\hline & \multicolumn{2}{|c|}{ Ringan } & \multicolumn{2}{|c|}{ Menengah } & \multicolumn{2}{|c|}{ Berat } & & & \\
\hline & $\mathrm{n}$ & $\%$ & $\mathrm{n}$ & $\%$ & $\mathrm{n}$ & $\%$ & $\mathrm{n}$ & $\%$ & \\
\hline Rendah & 3 & 6,7 & 25 & 55,6 & 17 & 37,8 & 45 & 100,0 & \\
\hline Menengah & 4 & 23,5 & 12 & 70,6 & 1 & 5,9 & 17 & 100,0 & 0,02 \\
\hline Tinggi & 4 & 50,0 & 2 & 25,0 & 2 & 25,0 & 8 & 100,0 & \\
\hline
\end{tabular}

Hasil analisis bivariat menggunakan uji ChiSquare, didapatkan nilai $p=0,004$ menunjukkan adanya hubungan yang bermakna antara kualitas tidur dengan dismenorea. Setelah dilakukan uji alternatif Mann Whitney, didapatkan bahwa responden dengan kualitas tidur buruk (Mean Rank 38,35) cenderung lebih berisiko mengalami dismenorea yang lebih berat. 
Variabel aktivitas fisik dan kualitas tidur memiliki $p<0,25$ sehingga dapat dimasukkan dalam uji regresi logistik. Analisis regresi logistik metode backward menunjukkan, variabel aktivitas fisik memiliki nilai $p$ sebesar 0,163 ( $p>0,05)$. Hal tersebut dapat diartikan bahwa variabel aktivitas fisik tidak bermakna dan dapat dieliminasi dari analisis regresi logistik. Berdasarkan analisis regresi logistik, hanya variabel kualitas tidur yang memiliki nilai $p<0,05$ sehingga dapat disimpulkan bahwa variabel kualitas tidur berhubungan secara bermakna dengan dismenorea derajat sedang dan berat. Responden yang memiliki kualitas tidur buruk memiliki peluang 0,027 kali untuk mengalami dismenorea dibandingkan responden yang memiliki kualitas tidur baik. Hal tersebut menunjukkan bahwa variabel yang paling dominan untuk mengalami dismenorea derajat sedang dan berat adalah kualitas tidur, karena nilai Odds Ratio (OR) variabel tersebut memiliki nilai paling tinggi setelah dikontrol oleh variabel aktivitas fisik.

Tabel 3. Analisis bivariat hubungan kualitas tidur dengan dismenorea pada mahasiswi Fakultas Kedokteran UPN “Veteran" Jakarta

\begin{tabular}{lccccccccc}
\hline \multicolumn{1}{c}{$\begin{array}{c}\text { Kualitas } \\
\text { tidur }\end{array}$} & \multicolumn{2}{c}{ Ringan } & \multicolumn{2}{c}{ Dismenorea } & \multicolumn{2}{c}{ Total } & \multicolumn{2}{c}{$\mathrm{p}$} \\
& $\mathrm{n}$ & $\%$ & $\mathrm{n}$ & $\%$ & $\mathrm{~N}$ & $\%$ & $\mathrm{n}$ & $\%$ & \\
\hline Baik & 8 & 66,7 & 1 & 8,3 & 3 & 25,0 & 12 & 100,0 & \multirow{2}{*}{0,04} \\
Buruk & 3 & 5,2 & 38 & 65,5 & 17 & 29,3 & 58 & 100,0 & \\
\hline
\end{tabular}

Pemilihan responden pada usia tersebut, sesuai dengan penelitian Kabirian et al bahwa dismenorea banyak dialami oleh perempuan muda dengan rentang usia 1825 tahun. $^{7}$ Pemilihan responden dengan onset menarche $\geq 12$ tahun didasarkan pada teori yang ada, bahwa terdapat hubungan antara onset menarche dengan dismenorea, karena saat menarche alat reproduksi belum siap untuk mengalami perubahan dan masih terjadi penyempitan pada leher rahim, maka akan timbul rasa sakit saat menstruasi. Ketika menstruasi, leher rahim akan melebar untuk mengeluarkan darah, pada onset menarche yang cepat, masih terjadi penyempitan leher rahim yang akan menimbulkan nyeri saat menstruasi, terutama bila darah haid yang keluar menggumpal, sehingga akan sangat terasa sakit saat melewati leher rahim. ${ }^{23}$

Teori tersebut didukung oleh penelitian Sophia et al bahwa terdapat hubungan antara usia menarche dengan kejadian dismenorea pada siswi SMK Negeri 10 Medan $(p=0,031) \cdot{ }^{24}$ Penelitian lain di Gorontalo oleh Pakaya, juga menunjukkan adanya hubungan usia menarche dengan dismenorea $(p=0,009)$, dimana remaja yang mengalami menarche yang lebih awal, berisiko 3,57 kali mengalami dismenorea primer. ${ }^{25}$

Keluhan dismenorea akan meningkat, seiring dengan kurangnya aktivitas fisik. Dampaknya pada uterus adalah aliran darah dan sirkulasi oksigen pun berkurang dan menyebabkan nyeri. Nyeri menstruasi 
terjadi karena peningkatan kontraksi otot uterus yang diinervasi oleh sistem saraf simpatis. Stres meningkatkan aktivitas simpatis yang akan memicu peningkatan derajat dismenorea dengan meningkatkan intensitas kontraksi uterus. Aktivitas fisik yang teratur seperti olahraga, akan mengurangi stres dengan menurunkan aktivitas simpatis, yang kemudian mengurangi intensitas dismenorea dan gejala lain. Mekanisme lain adalah aktivitas fisik akan memicu sekresi endorfin, yaitu molekul-molekul protein hasil produksi beta-lipotropin yang ditemukan di kelenjar pituitari, yang akan meningkatkan ambang batas nyeri sehingga menurunkan sensitivitas terhadap nyeri. ${ }^{26}$ Sesuai dengan teori endorfin-enkefalin mengenai pemahaman mekanisme nyeri, yaitu ditemukannya reseptor opiat di membran sinaps dan kornu dorsalis medula spinalis. Terdapat tiga golongan utama peptida opioid endogen, yaitu golongan enkephalin, beta-endorphin, dan dinorphin. Beta-endorphin yang dikeluarkan saat olahraga sangat efektif untuk mengurangi rasa nyeri. ${ }^{27}$ Selain menginduksi pelepasan opiat endogen seperti beta endorfin, aktivitas fisik juga akan menyebabkan vasodilatasi, supresi PG, dan reduksi stres serta perubahan mood. ${ }^{28}$

Penelitian Chantler et al mendukung hasil penelitian ini, yaitu dismenorea primer memilki hubungan dengan aktivitas fisik yang dilakukan sehari-hari, sehingga aktivitas fisik dapat digunakan sebagai salah satu cara dalam memperbaiki nyeri. ${ }^{29}$
Penelitian lain juga memiliki hasil serupa, seperti hasil penelitian Atta et al yang menyatakan bahwa perempuan yang sangat aktif beraktivitas fisik, akan merasakan derajat nyeri yang lebih rendah daripada perempuan yang kurang melakukan aktivitas fisik $(p=0,019) \cdot{ }^{30}$ Hasil penelitian Kannan et al menunjukkan hasil serupa, bahwa aktivitas fisik dengan intensitas sedang seperti olahraga, memiliki potensi yang baik sebagai penatalaksanaan dismenorea. ${ }^{31}$

Melakukan aktivitas fisik secara teratur, mampu mengurangi gejala dismenorea, karena aktivitas fisik membantu mempercepat transportasi PG dalam jumlah besar, sehingga PG tidak terakumulasi berlebih pada dinding uterus, yang kemudian mengurangi rasa nyeri. ${ }^{32}$ Olahraga merupakan salah satu manajemen non farmakologis yang lebih aman digunakan karena menggunakan proses fisiologis. Penelitian Sophia et al menyatakan bahwa terdapat hubungan yang bermakna antara kebiasaan olahraga dengan kejadian dismenore. ${ }^{24}$ Aktivitas fisik teratur dapat meningkatkan jumlah dan ukuran pembuluh darah yang menyalurkan darah ke seluruh tubuh termasuk organ reproduksi, sehingga aliran darah menjadi lancar dan hal tersebut dapat menurunkan gejala dismenore. Peningkatan volume darah yang mengalir ke seluruh tubuh termasuk organ reproduksi akan melancarkan pasokan oksigen ke pembuluh darah yang mengalami vasokontriksi, sehingga dismenore dapat berkurang. ${ }^{33}$ 
Menurut Lautenbacher et al, kualitas tidur yang buruk dihubungkan dengan proses terjadinya nyeri. ${ }^{34}$ Studi terhadap relawan yang sehat oleh Haack et al menunjukkan bahwa, pengurangan waktu tidur selama 4 jam, dapat meningkatkan mediator nyeri seperti PG dan agen inflamasi seperti Interleukin-6 (IL-6) dan Tumor Necrosis Factor Alpha $\left(\mathrm{TNF}_{\alpha}\right)$ sehingga mencetuskan nyeri yang poten. ${ }^{35}$ Berkurangnya kadar serotonin di dalam tubuh akibat kualitas tidur yang buruk akan meningkatkan sensitivitas terhadap nyeri, timbulnya kecemasan dan depresi. ${ }^{36}$

Studi pendahuluan menemukan bahwa perempuan dengan insomnia, mengalami nyeri menstruasi lebih berat dibandingkan perempuan tanpa insomnia. ${ }^{20}$ Oleh sebab itu, gangguan tidur akan semakin meningkatkan sensitivitas mereka terhadap nyeri, sehingga meningkatkan derajat dismenorea yang dialami. ${ }^{22}$ Hasil penelitian ini serupa dengan hasil penelitian Yudhanti et al, bahwa kualitas tidur yang buruk memiliki risiko yang lebih besar dalam meningkatkan derajat dismenorea. ${ }^{37}$

Kualitas tidur yang buruk akan memicu terjadinya stres. Ketika stres, tubuh akan menghasilkan hormon adrenalin, estrogen, progesteron, dan PG yang berlebihan. Estrogen dapat menyebabkan peningkatan kontraksi uterus secara berlebihan sedangkan progesteron bersifat menghambat kontraksi. Peningkatan kontraksi yang berlebihan ini menyebabkan rasa nyeri. Selain itu, hormon adrenalin yang juga meningkat, akan menyebabkan otot tubuh tegang termasuk otot rahim, sehingga menimbulkan nyeri ketika menstruasi. ${ }^{38}$

Orlandi et al memperoleh hasil penelitian bahwa, perempuan yang memaksimalkan kualitas tidur, mengurangi konsumsi kafein dan alkohol, akan mengalami penurunan sensitivitas nyeri pada 3 bulan kemudian. ${ }^{39}$ Hasil penelitian ini juga sejalan dengan hasil penelitian Roehrs et al yang membuktikan, bahwa penambahan durasi tidur terbukti menurunkan sensitivitas seseorang terhadap nyeri. ${ }^{40}$ Selain itu, Heneweer et al dalam penelitiannya juga menyatakan, bahwa nyeri adalah suatu kondisi kompleks yang dipengaruhi oleh aktivitas tubuh dan kualitas tidur. ${ }^{41} \mathrm{Hal}$ ini didukung oleh teori, bahwa perempuan pada rentang usia 18-25 tahun, membutuhkan tidur selama 7-9 jam setiap harinya. Jika kebutuhan tidur tersebut tidak terpenuhi, tentunya akan memperburuk kualitas tidur, yang nantinya akan mengganggu proses fisiologis tubuh, salah satunya peningkatan sensitivitas tubuh terhadap nyeri. Maka dapat dikatakan bahwa, peningkatan sensitivitas nyeri akibat buruknya kualitas tidur ini, akan berdampak langsung pada beratnya derajat dismenorea. ${ }^{42}$

\section{SIMPULAN}

Penelitian ini membuktikan bahwa terdapat hubungan yang bermakna antara aktivitas fisik dengan dismenorea pada mahasiswi Fakultas Kedokteran UPN "Veteran" Jakarta ( $p=0,002)$. Selain itu, kualitas tidur juga memiliki hubungan yang 
bermakna dengan dismenorea pada mahasiswi Fakultas Kedokteran UPN "Veteran" Jakarta $(p=0,004)$. Kualitas tidur menunjukkan hubungan yang lebih kuat dengan dismenorea daripada aktivitas fisik.

\section{DAFTAR PUSTAKA}

1. Calis KA. Dysmenorrhea: practice essentials, background, pathophysiology. Medscape. 2017 [Disitasi pada 2017 Aug 10]; 1-18. Tersedia di: https://emedicine.medscape.com/article/253812overview\#a6

2. Al-Kindi R, Al-Bulushi A. Prevalence and impact of dysmenorrhea among Omani High School Students. Sultan Qaboos University Medical Journal; 2011 [Disitasi pada 2017 Sep 5]: 11(4): 485491. Tersedia di: https://www.ncbi.nlm.nih.gov/pubmed/22087397

3. Pitangui AC, Gomes MR, Lima AS, Schwingel PA, Albuquerque AP, de Araujo RC. Menstrual disturbances: prevalence, characteristics, and effects on the activities of daily living among adolescent girls from brazil. Journal of Pediatric and Adolescent Gynecology; 2013 [Disitasi pada 2017 July 25]: 26(3): 148-152. Tersedia di: https://www.ncbi.nlm.nih.gov/pubmed/23507005

4. Kazama M, Maruyama K, Nakamura K. Prevalence of dysmenorrhea and its correlating lifestyle factors in Japanese female junior high school students. Tohoku J. Exp. Med; 2015 [2017 July 29]: 236: 107-113. Tersedia di: https://www.jstage.jst.go.jp/article/tjem/236/2/236 107/ pdf/char/en

5. International Association for The Study of Pain. Dysmenorrhea: Contemporary Perspectives. Pain Clinical Updates; 2007 [Disitasi pada 2017 July 25]: XV: Issue 8. Tersedia di: https://s3.amazonaws.com/rdcmsiasp/files/production/public/Content/ContentFolders/Publicat ions2/PainClinicalUpdates/Archives/PCU078 1390262758258 9.pdf

6. Ostrzenski A. Dysmenorrhea. Gynecology Integrating Conventional, Complementary and Natural Alternative Therapies, Philadelphia, PA: Lippincott Williams \& Wilkins; 2002 [Disitasi pada 2017 July 25]: 10. Tersedia di:

https://www.sciencedirect.com/science/article/pii/S1524904215001022\#bib18

7. Kabirian M, Abedian Z, Mazlom SR, Mahram B, Jalalian M. Self-management in primary dysmenorrhea: toward evidence-based education. Life Science Journal; 2011 [Disitasi pada 2017 Aug 10]: 8(2): 13-18. Tersedia di: https://www.researchgate.net/publication/285928997SelfmanagementinPrimary Dysmenorrhe a Toward Evidence-based Education

8. Okoro RN, Malgwi H, Okoro GO. Evaluation of factors that increase the severity of dysmenorrhea among university female students in Maiduguri, North eastern Nigeria. Internet Journal of Allied Health Sciences and Practice; 2013 [2017 Aug 10]: 11(4): 1-10. Tersedia di:

https://nsuworks.nova.edu/ijahsp/vol11/iss4/7/

9. Kural M, Noor NN, Pandit D, Joshi T, Patil A. Menstrual characteristics and prevalence of dysmenorrhea in college going girls. J Family Med Prim Care India: Medknow Publications \& Media Pvt Ltd; 2015 [2017 Aug 2]: 4(3): 31. Tersedia di: https://www.ncbi.nlm.nih.gov/pmc/articles/PMC4535108/ 
10. Proctor ML, Farquhar CM. Dysmenorrhea. British Medical Journal; 2007 [Disitasi pada 2017 Aug 2]: 3: 813-838. Tersedia di: https://www.ncbi.nlm.nih.gov/pubmed/19454059

11. Proverawati A, Misaroh S. Menarche Menstruasi Pertama Penuh Makna. Yogyakarta: Nuha Medika.

12. World Health Organization. Global recommendations on physical activity for health. WHO Press. 2018 [Disitasi pada 2018 Jan 10]. Tersedia di:

http://www.who.int/dietphysicalactivity/factsheetrecommendations/en/

13. Diana R, Yuliana I, Yasmin G, Hardinsyah. Faktor risiko kegemukan pada wanita dewasa Indonesia. Jurnal Gizi dan Pangan. 2013 [Disitasi pada 2017 Aug 7]; 8(1): 1-8. Tersedia di: http://journal.ipb.ac.id/index.php/igizipangan/article/view/7226

14. Saadah S. Hubungan Aktivitas Fisik dengan Dismenore Pada Mahasiswi Program Studi Ilmu Keolahragaan. Skripsi Fakultas Pendidikan dan Kesehatan Universitas Pendidikan Indonesia Bandung. 2014 [Disitasi pada 2017 July 20]. Tersedia di: http://repository.upi.edu/6594/2/SIKOR0900071Abstract.pdf

15. Harrington SA. Relationships of objectively measured physical activity and sleep with BMI and academic outcomes in 8-year-old children. Applied Nursing Research: ANR. 2013 [Disitasi pada 2017 July 22]; 26(2): 63-70. Tersedia di: https://www.ncbi.nlm.nih.gov/pubmed/23583266

16. Hidayat AA. Pengantar Konsep Dasar Keperawatan. Jakarta: Salemba Medika; 2008.

17. Smith M. The effects of sleep deprivation on pain inhibition and spontaneous pain in women. Sleep. 2007 [Disitasi pada 2017 Aug 2]; 30: 494-505. Tersedia di: https://www.ncbi.nlm.nih.gov/pubmed/17520794

18. Brown FC, Buboltz WC, Soper B. Development and evaluation of the sleep treatment and education program for students. Journal of American College Health. 2006 [Disitasi pada 2017 Aug 1]; 54: 231-237. Tersedia di: https://www.ncbi.nlm.nih.gov/pubmed/16450848

19. Abdulghani HM, Alrowais NA, Bin-Saad NS, Al-Subaie NM, Haji AM, Alhaqwi AI. Sleep disorder among medical students: relationship to their academic performance. Med Teach. 2012 [Disitasi pada 2017 Aug 8]: 37-41. Tersedia di: https://www.ncbi.nIm.nih.gov/pubmed/22409189

20. Woosley JA, Lichstein KL. Dysmenorrhea, the menstrual cycle and sleep. Behavioral Medicine. 2014 [Disitasi pada 2018 Aug 3]; 40(1): 14-21. Tersedia di:

https://www.ncbi.nlm.nih.gov/pubmed/24512361

21. Azevedo E, Manzano GM, Silva A, Martins R, Andersen MI, Tufik S. The effects of total and REM sleep deprivation on laser-evoked potential threshold and pain perception. Pain. 2011 [Disitasi pada 2017 Oct 2]; vol. 153: 2052-2058. Tersedia di: https://www.ncbi.nlm.nih.gov/pubmed/21624774

22. Lacovides S, Avidon I, Bentley A, Baker FC. Diclofenac potassium restores objective and subjective measures of sleep quality in women with primary dysmenorrhea. PubMed. 2009 [Disitasi pada 2017 Oct 1]; 32(8): 26. Tersedia di: https://www.ncbi.nlm.nih.gov/pubmed/19725253

23. Widjanarko B. Dismenore Tinjauan Terapi Pada Dismenore Primer. Majalah Kedokteran Damianus; 2006: 5(16).

24. Sophia F, Muda S, Jenadi. Faktor-faktor yang berhubungan dengan dismenore pada siswi smk negeri 10 medan tahun 2013. Jurnal Gizi, Kesehatan Reproduksi, dan Epidemiologi. 2013 [Disitasi 
pada 2017 Des 1]; 2(5): 1-10. Tersedia di:

https://jurnal.usu.ac.id/index.php/gkre/article/view/4060/1894

25. Pakaya D. Hubungan faktor risiko dengan kejadian dismenore primer pada siswi kelas VIII SMPN 6 Gorontalo Tahun 2013. Skripsi Fakultas IImu-ilmu Kesehatan dan Keolahragaan Universitas Negeri Gorontalo. 2013 [Disitasi pada 2018 Jan 1]. Tersedia di: http://kim.ung.ac.id/index.php/KIMFIKK/article/download/2844/2820

26. Sherwood L. Human Physiology From Cell to Systems 9th Edition. Canada: Cengage Learning; 2016.

27. Ehrenthal D, Hoffman M, Hillard PA. Menstrual disorders. USA: ACP Press; 2006.

28. Lumsden MA. Dysmenorrhoea. Women's Health Medicine. 2005 [Disitasi pada 2018 Feb 2]; 2: 40-43. Tersedia di: https://www.sciencedirect.com/science/article/pii/S1744187006000266

29. Chantler I, Mitchel D, Fuller A. Actigraphy quantifies reduced voluntary physical activity in women with primary dysmenorrhea. Journal of Pain. 2009 [Disitasi pada 2018 Feb 2]; 10: 38-46. Tersedia di: https://www.ncbi.nlm.nih.gov/pubmed/18722817

30. Atta K, Jawed S, Zia S. Correlating primary dysmenorrhea with its stressors: a cross sectional study investigating the most likely factors of primary dysmenorrhea and its effects on quality of life and general well being. JUMDC. 2016 [Disitasi pada 2017 Des 20]; 7: Issue 4: 1-9. Tersedia di: http://jumdc.tuf.edu.pk/articles/volume-7-4/43-50.pdf

31. Kannan P, Claydon LS, Miller D, Chapple CM. Vigorous exercises in the management of primary dysmenorrhea: a feasibility study. 2015 [Disitasi pada 2018 Feb 1]; 37(15): 1334-1339. Tersedia di: https://www.ncbi.nlm.nih.gov/pubmed/25243766

32. Mahvash N, Eidy A, Mehdi K, Zahra MT, Mani M, Shahla H. The effect of physical activity on primary dysmenorrhea of female university students. World Applied Sciences Jornal. 2012 [Disitasi pada 2017 Des 22]; vol. 17(10): 1246-1252. Tersedia di: https://pdfs.semanticscholar.org/4fcc/112b2a236c5275f76a762aa2f3633c9530a6.pdf

33. Laili N. Perbedaan tingkat nyeri haid sebelum dan sesudah senam dismenore pada remaja putri di SMAN 2 Jember. Skripsi Program Studi Ilmu Keperawatan Universitas Jember. 2012 [Disitasi pada 2018 Feb 2]. Tersedia di:

http://repository.unej.ac.id/bitstream/handle/123456789/10822/Nurul\%20Laili.pdf?sequence= $\underline{1}$

34. Lautenbacher S, Kundermann B, Krieg J. Sleep deprivation and pain perception. Sleep Medicine Reviews. 2006 [Disitasi pada 2018 Jan 1]; 10: 357-369. Tersedia di:

https://www.ncbi.nlm.nih.gov/pubmed/16386930

35. Haack M, Scott-Sutherland J, Santangelo G, Simpson NS, Sethna N, Mullington JM 2012. Pain sensitivity and modulation in primary insomnia. European Journal of Pain. 2012 [Disitasi pada 2018 Feb 3]; 16: 522-533. Tersedia di:

https://www.ncbi.nlm.nih.gov/pmc/articles/PMC3627385/pdf/nihms452932.pdf

36. Mcllwain HH, Bruce DF. Diet for a Pain-Free Life: A Revolutionary Plan to Lose Weight, Stop Pain, Sleep Better and Feel Great in 21 Days. Marlowe \& Company; 2007.

37. Yudhanti MD. Hubungan Kualitas Tidur dengan Kejadian Dismenore Primer pada Mahasiswi Fakultas Kedokteran Universitas Sebelas Maret. Skripsi Fakultas Kedokteran Universitas Sebelas Maret Surakarta. 2014 [Disitasi pada 2017 July 25]. Tersedia di: https://eprints.uns.ac.id/16537/ 
38. Prawirohardjo S. Ilmu Kandungan Edisi 3. Jakarta: Yayasan Bina Pustaka; 2008.

39. Orlandi AC, Ventura C, Gallinaro AL, Costa RA, Lage LV. Improvement in pain, fatigue, and subjective sleep quality through sleep hygiene tips in patients with fibromyalgia. Rev Bras Reumatol. 2012 [Disitasi pada 2018 Jan 1]; 52: 666-678. Tersedia di: http://www.scielo.br/pdf/rbr/v52n5/env52n5a03.pdf

40. Roehrs TA, Harris E, Randall S, Roth T. Pain sensitivity and recovery from mild chronic sleep loss. Sleep. 2012 [Disitasi pada 2017 July 20]; 35: 1667-1672. Tersedia di:

https://www.ncbi.nlm.nih.gov/pmc/articles/PMC3490359/pdf/aasm.35.12.1667.pdf

41. Heneweer $\mathrm{H}$, Vanhees L, Picavet HSJ. Physical activity and low back pain: A U-shaped relation?. Pain. 2009 [Disitasi pada 2017 July 28]; 143: 21-25. Tersedia di:

https://www.ncbi.nlm.nih.gov/pubmed/19217208

42. Hirshkowitz M, Whiton K, Albert SM, Alessi C, Bruni O, DonCarlos L, Hazen N, Herman J, Katz ES, Kheirandish-Gozal L, Neubauer DN, O'Donnell AE, Ohayon M, Peever J, Rawding R, Sachdeva RC, Setters B, Vitiello MV, Ware JC, Hillard PJA. National sleep foundation's sleep time duration recommendations: methodology and results summary. Sleep Health Journal of the National Sleep Foundation. 2015 [Disitasi pada 2018 Feb 1]; 1: 40-43. Tersedia di:

http://www.sleephealthjournal.org/article/S2352-7218(15)00015-7/pdf 